\title{
Study Structure and Properties of Reinforcing Rolled Coils by V-Alloyed C - Mn - Si - Steel with Dual- and Multi-Phase Microstructures
}

\author{
V. L. Plyuta ${ }^{1}$, S. A. Vorobey ${ }^{1}$, G. V. Levchenko ${ }^{1}$, A. B. Sychkov ${ }^{2} \&$ A. M. Nesterenko ${ }^{1}$ \\ ${ }^{1}$ Iron and Steel Institute of the National Academy of Sciences, Dnepr, Ukraine \\ ${ }^{2}$ Nosov Magnitogorsk State Technical University, Magnitogorsk, Russia \\ Correspondence: A. B. Sychkov, Nosov Magnitogorsk State Technical University, Magnitogorsk, Russia. E-mail: \\ nestav1946@mail.ru
}

Received: August 18, 2017

Accepted: September 5, 2017

Online Published: September 20, 2017

doi:10.5539/jmsr.v6n4p79

URL: https://doi.org/10.5539/jmsr.v6n4p79

\begin{abstract}
Thermo-mechanical controlled rolling (TMCR) schedules have been studied on the wire line of 400/200 section rolling mill to manufacture 6.0 - $\mathrm{mm}$ - diameter reinforcing wire in coils by $\mathrm{V}$-alloyed $\mathrm{C}-\mathrm{Mn}-\mathrm{Si}$ - steel that has dual-phase (DP - ferrite-martensite (bainite)) and multi-phase (MP - ferrite-martensite (bainite) - pearlite) microstructures.

It has been established that high tensile strength and plasticity values were achieved in this $6.0-\mathrm{mm}$ wire in coils $\left(\mathrm{YS}_{0.2}=530-550 \mathrm{MPa} ; \mathrm{TS}=785-885 \mathrm{MPa} ; \mathrm{El}_{5}=15.0-29.0 \%\right)$ which were in full compliance with national standard specifications such as ASTM A 615 (USA), JIS G 3112 (Japan) and KSD 3504 (the Republic of Korea)), when the TMCR schedules involving laying head temperatures $\mathrm{T}_{\mathrm{LH}}$ from $1024{ }^{\circ} \mathrm{C}$ to $1063{ }^{\circ} \mathrm{C}$ were employed ensuring formation of MP microstructure.
\end{abstract}

Keywords: thermo-mechanical controlled rolling, 400/200 section rolling mill, wire line, reinforcing wire in coils, $\mathrm{V}$ - micro - alloyed C - Mn - Si - steel, dual-phase (DP - ferrite-martensite (bainite)), multi-phase (MP ferrite-martensite (bainite) - pearlite), microstructure, tensile strength and plasticity

\section{Introduction}

Thanks to a unique combination of tensile strength and placticity properties, high strength low-alloyed dual- and multi - phase (DP - and MP, respectively) steels are usefully applied in the automotive industry for weight reduction of cold-formed components, in the heading industry, in the gas and oil industry for manufacture of transmission pipelines, including those laid in seismic and permafrost regions (Lis, Lis, \& Kolan, 2004; Zuo \& Zhou, 2015; Sychkov, Zhigarev, \& Perchatkin, 2006; Sychkov, Sheksheev, Malashkin, \& Kamalova, 2016; Xu \& Kong, 2012). Recently, high strength reinforcing steel wires with DP - and MP microstructures have found wide application in the construction industry.

Principally, to obtain DP - and MP microstructures in low-alloyed steel rolled products two methods are applied: heat treatment and thermo-mechanical controlled rolling (TMCR) (Figure 1) (Lis, Lis, \& Kolan, 2004).

The heat treatment method (Figure 1, left-hand side) involves heating of steel to $1063 \mathrm{~K}\left(790{ }^{\circ} \mathrm{C}\right)$, a dual-phase ( $\alpha$ $+\gamma$ ) temperature range (intercritical temperature range (ICTR)), annealing at that temperature for a certain time, quenching in water for obtaining martensite islands in the structure, and tempering at $913 \mathrm{~K}$ (normally, $500-550{ }^{\circ} \mathrm{C}$ ) to relief stresses and to reduce aging effects. There are numerous versions of the above described heat treatment method that are applied in continuous annealing furnaces for commercial production of cold rolled plates from low-alloyed DP - and MP steels. A TMCR method involving controlled cooling of hot - rolled steel products is shown in Figure 1 (on the right). A schematic overlay of the lines of austenite phase transformation in low-alloyed steels (continuous-cooling transformation diagram, CCT-diagram) in the controlled cooling temperature range shows, that martensite/pearlite islands in the structure of low carbon steel to an extent of 15-20\%, which ensure the highest tensile strength and hardness $(\mathrm{HB}=371$, Figure 1$)$, are formed from microareas of austenite $(\gamma$-phase) left untransformed in this steel at $873 \mathrm{~K}\left(600^{\circ} \mathrm{C}\right)$ (after the completion of $\gamma \rightarrow \alpha-$ transformation) as a result of quenching in water. Development of TMCR method for commercial production of high strength and 
high-technology types of hot rolled plates, bars and wire rods from low-alloyed DP - and MP steels has been the subject of numerous investigations, but mainly on the laboratory level.

A comprehensive study of prospects for the application of 5.5-mm-diameter low - carbon wire rod $(0.08 \mathrm{C} ; 0.77$ $\mathrm{Mn} ; 0.21 \mathrm{Si} ; 0.017 \mathrm{P} ; 0.012 \mathrm{~S}$, in \% by weight) with DP microstructure in the construction industry is so interest (Lorusso, Burgueno, Egidi, \& Svoboda, 2012). A DP microstructures in the laboratory samples of wire rod under study were obtained by a heat treatment process, that involved annealing them at ICTR $\left(795,810,820\right.$ and $\left.840{ }^{\circ} \mathrm{C}\right)$ for 15 minutes and quenching in water. Micro-structural characteristics, hardness and mechanical properties of the these samples were analyzed and compared with similar parameters of ATR $500 \mathrm{~N}$ cold deformed reinforcement wire manufactured in accordance with IRAM-IAS U500 526, Argentina (Table 1).

The experimental data allowed the authors of work to conclude, that values of strength properties (Lorusso, Burgueno, Egidi, \& Svoboda, 2012), TS / YS 0.2 - ratio, ultimate elongation $\mathrm{El}_{10}$, Vickers hardness (HV) were close to these obtainable in commercial ATR $500 \mathrm{~N}$ cold deformed reinforcement wire, could be observed in a obtained wire with a high volume (50\%) fraction of martensite after Extension Underload of $2 \%$ (Table 1, DP 820 (2\% EUL)). They state, that the obtained materials had a greater capacity of energy absorption and likewise a higher strength exponent, than traditional commercial products (ATR 500N), thus offering a promising potential for their use in construction in seismic zones.

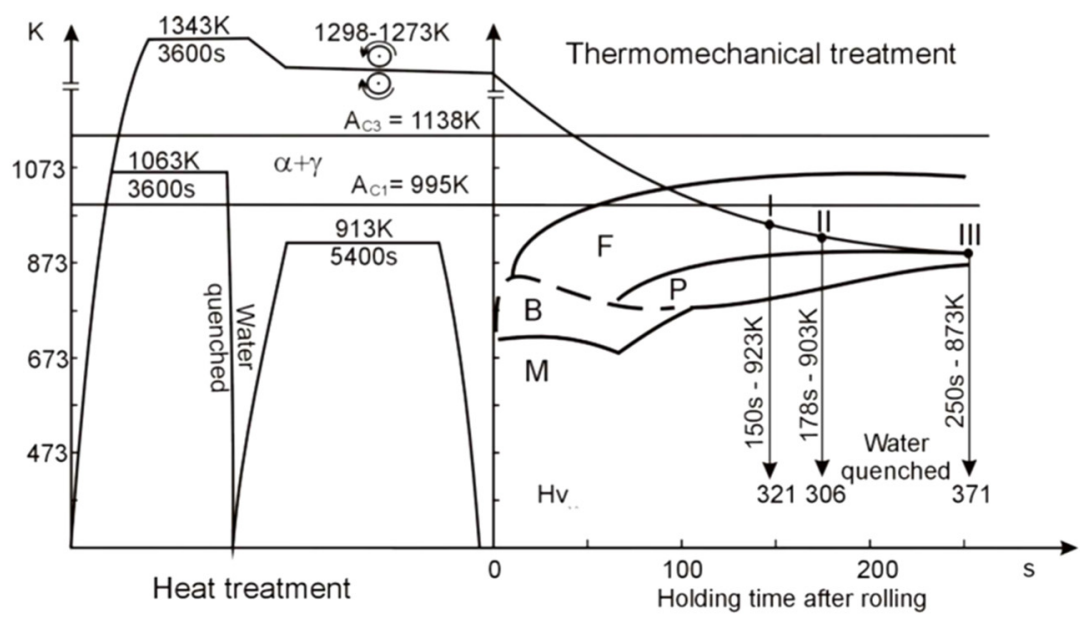

Figure 1. Schematic diagram of heat treatment and TMCR schedules that are applied for obtaining DP - and MP structures in low-alloyed steel rolled products (Lis, Lis, \& Kolan, 2004)

Table 1. Micro-structural characteristics, hardness and mechanical properties of 5.5-mm-diameter low - carbon wire rod (Lorusso, Burgueno, Egidi, \& Svoboda, 2012)

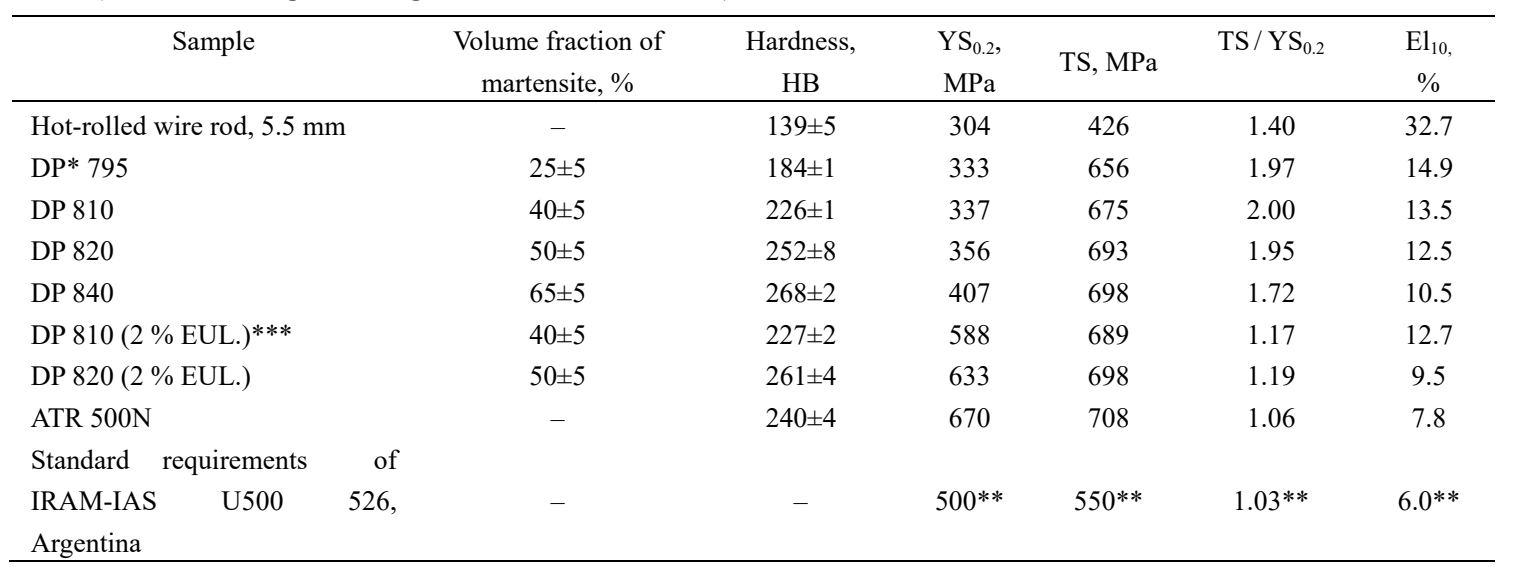

* DP - steel wire rod, the digital designations - the temperatures of samples' holding at the ICTR.

** Minimum value.

*** 2\% EUL (Extension Underload of 2\%) was applied to simulate cold-deformation induced stresses in steel by the ribbing of the wire's surface. 
Hot - rolled reinforcing wire in coils can vary in chemical composition and mechanical properties. It, for instance, was shown by the basic standard specifications ASTM A615/A615M (USA), JIS G 3112 (Japan) and KSD 3504 (the Republic of Korea) (Table 2 - 5).

According to ASTM A 615/A615M (USA), hot - rolled reinforcing wires in coils Gr. $40\left(\mathrm{YS}_{0.2} \geq 300 \mathrm{~N} / \mathrm{mm}^{2}\right.$ ) and Gr. 60 (YS ${ }_{0.2} \geq 420 \mathrm{~N} / \mathrm{mm}^{2}$ ) are manufactured from semi-killed carbon steel (Table 2) and low-alloyed carbon steel (Table 3) respectively.

According to Japanese and Korean national standards, hot - rolled reinforcing wires in coils of different strength classes are manufactured from the same grade of low-alloyed steel (Tables 4, 5).

However, they require calculating the carbon equivalent, $\mathrm{Ceq}$ (Tables 4, 5), which is derived from the following equation:

$$
C_{e q}=C+\frac{M n}{6}
$$

Table 2.

\begin{tabular}{lcccc}
\hline Country, standard specification & Class of reinforcing steel & YS $_{0.2}, \mathrm{MPa}$ & $\mathrm{TS}, \mathrm{MPa}$ & $\mathrm{El}, \%$ \\
\hline \multirow{2}{*}{ USA, ASTM A615/A615M } & $\mathrm{Gr} .40(300)$ & $\geq 300$ & $\geq 420$ & $\mathrm{El}_{200} \geq 11$ \\
& $\mathrm{Gr} 60(420)$ & $\geq 420$ & $\geq 620$ & $\mathrm{El}_{200} \geq 9$ \\
& $\mathrm{SD} \mathrm{40}$ & $390-510$ & $\geq 560$ & $\mathrm{El}_{5} \geq 16$ \\
Japan, JIS G 3112 & $\mathrm{SD} \mathrm{50}$ & $490-625$ & $\geq 620$ & $\mathrm{El}_{5} \geq 12$ \\
\multirow{2}{*}{ The Republic of Korea, KSD 3504 } & $\mathrm{SD} \mathrm{40}$ & $392-510$ & $\geq 559$ & $\mathrm{El}_{5} \geq 16$ \\
& $\mathrm{SD} \mathrm{50}$ & $490-528$ & $\geq 618$ & $\mathrm{El}_{5} \geq 12$ \\
\hline
\end{tabular}

Table 3. Chemical composition as per ASTM A 615 (USA)

\begin{tabular}{cccccc}
\hline Class of rolled & \multicolumn{5}{c}{ Elements in \% by wt. (less than or equal to) } \\
\cline { 2 - 5 } product & $\mathrm{C}$ & $\mathrm{Mn}$ & $\mathrm{Si}$ & $\mathrm{S}$ & $\mathrm{P}$ \\
\hline Gr 40 & $0.28-0.38$ & $0.50-0.80$ & 0.10 & 0.050 & 0.040 \\
Gr 60 & $0.32-0.38$ & $0.80-1.20$ & $0.60-0.90$ & 0.045 & 0.040 \\
\hline
\end{tabular}

Table 4. Chemical composition as per JIS G 3112 (Japan)

\begin{tabular}{|c|c|c|c|c|c|c|}
\hline \multirow{2}{*}{ Class of rolled product } & \multicolumn{5}{|c|}{ Elements in \% by wt. (less than) } & \multirow[t]{2}{*}{$\mathrm{C}_{\mathrm{eq}}, \%$ (less than) } \\
\hline & $\mathrm{C}$ & $\mathrm{Si}$ & $\mathrm{Mn}$ & $\mathrm{P}$ & $\mathrm{S}$ & \\
\hline SD390 & 0.29 & 0.55 & 1.80 & 0.040 & 0.040 & 0.55 \\
\hline SD490 & 0.32 & 0.55 & 1.80 & 0.040 & 0.040 & 0.60 \\
\hline
\end{tabular}

Table 5. Chemical composition as per KSD 3504 (the Republic of Korea)

\begin{tabular}{ccccccccc}
\hline $\begin{array}{c}\text { Class of rolled } \\
\text { product }\end{array}$ & \multicolumn{9}{c}{ Elements in \% by wt. (less than) } & \multicolumn{2}{c}{$\mathrm{C}_{\text {eq, }} \%$ (less } \\
than)
\end{tabular}

Today, Mesh and Welded Wire Concrete Reinforcement (WWR) technology, which has been intensively developing (Wire Enforcement Institute (WRI), 2014), is using considerable quantities (up to 50\% of the total consumption of reinforcing steels) of the reinforcing wires in diameters up to $12 \mathrm{~mm}$ in coils. Reinforcing wires in coils has the merit of being suitable to automatic machine welding of meshes, fabrics, embedded light reinforcing materials, generating no or low waste such as short ends, as distinct from reinforcing steel in cut lengths, which can generate minimum $5-7 \%$ of this type of waste. There is a high demand for reinforcing wires in coils in the construction industry (up to $90 \%$ of the total demand for reinforcing steels in diameters up to $12 \mathrm{~mm}$ ). It is thus important to study structural and mechanical characteristics of reinforcing wires in coils made from low-alloyed DP - and MP steels subjected to treatment by TMCR on the wire line of a section rolling mill. 


\section{Materials and Research Techniques}

Considering the increasing demand for reinforcing wire in coils with higher tensile strength properties $\left(\mathrm{YS}_{0.2}>400\right.$ MPa) (Lorusso, Burgueno, Egidi, \& Svoboda, 2012; Wire Enforcement Institute (WRI), 2014), C - Mn - C - steel micro-alloyed by V was used as a test steel in plant experiments carried out on the wire line of a 400/200 section rolling mill with the aim to develop production methods for these rolled products, with a referenced low - carbon steel micro-alloyed by B. Chemical compositions of the steels are listed in Table 6 . The layout of the wire block with a STELMOR line (400/200 rolling mill) is shown in Figure 2.

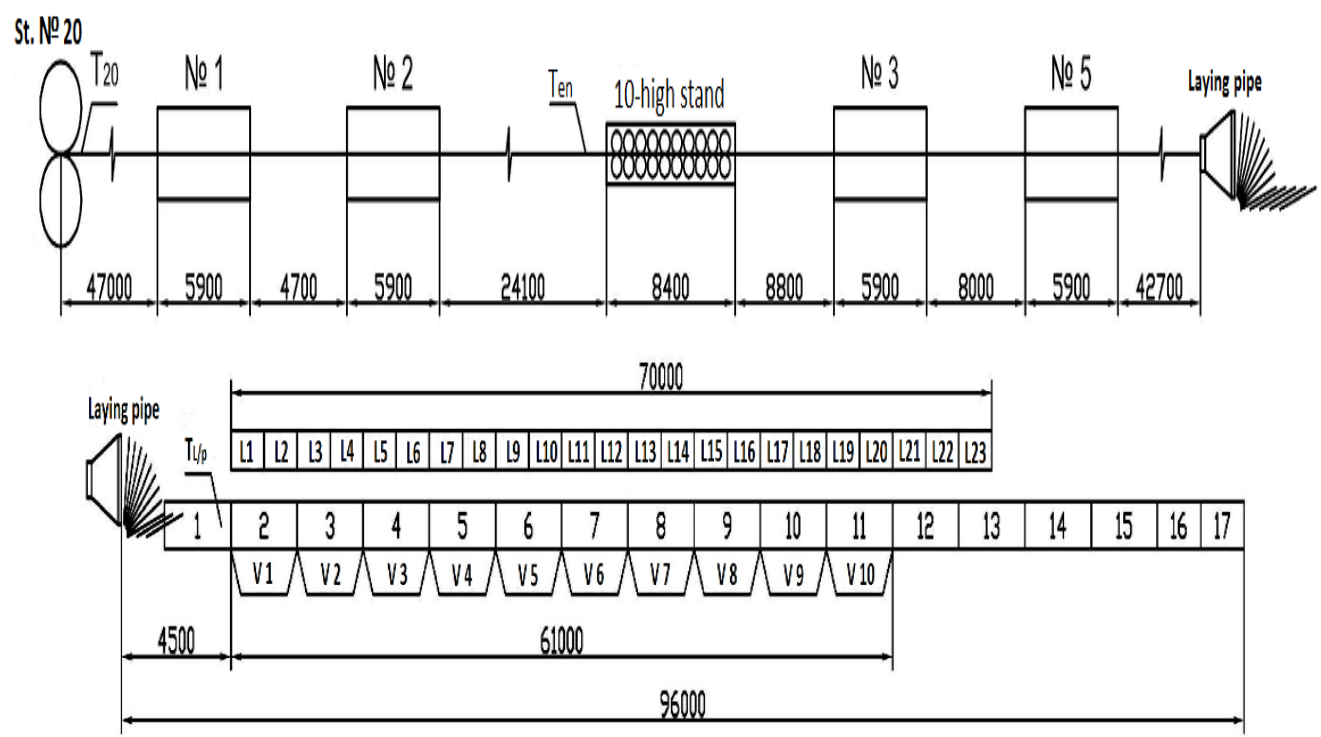

Figure 2. Schematic diagram of a 400/200 rolling mill with a STELMOR line: $T_{20}$ - the last stand (stand № 20); No.1-5 - water cooling boxes; $\mathrm{T}_{\mathrm{en}}-10$-stand finishing block; laying pipe (laying head); $\mathrm{L}_{1}-\mathrm{L}_{23}$ - thermo-insulated covers; $1-17$ - sections of the wire rod conveyor; $\mathrm{V}_{1}-\mathrm{V}_{10}-$ blowers.

Table 6. Chemical composition of the steels under study

\begin{tabular}{ccccccccccc}
\hline \multirow{2}{*}{ Steel grade } & \multicolumn{7}{c}{ Chemical composition in \% by wt. } \\
\cline { 2 - 10 } & $\mathrm{C}$ & $\mathrm{Mn}$ & $\mathrm{Si}$ & $\mathrm{S}$ & $\mathrm{P}$ & $\mathrm{Cr}$ & $\mathrm{Ni}$ & $\mathrm{V}$ & $\mathrm{B}$ \\
\hline $\begin{array}{c}\text { Micro-alloyed by V } \\
\mathrm{C}-\mathrm{Mn}-\mathrm{Si} \text { - steel }\end{array}$ & 0.17 & 1.25 & 0.75 & 0.002 & 0.016 & 0.02 & 0.02 & 0.112 & - \\
$\begin{array}{c}\text { Referenced micro-alloyed } \\
\text { by B low - carbon steel }\end{array}$ & 0.21 & 1.02 & 0.27 & 0.002 & 0.016 & 0.04 & 0.02 & 0.001 & 0.006 \\
\hline
\end{tabular}

The choice of $\mathrm{V}$ as a micro-alloying element of low - alloyed $\mathrm{C}-\mathrm{Mn}-\mathrm{Si}$ - steel was based on its high ability to form carbides and nitrides in these steels in the austenite transformation region during cooling through a wide range of temperatures $\left(\Delta \mathrm{T}-\right.$ from $1060-1080{ }^{\circ} \mathrm{C}$ to $400{ }^{\circ} \mathrm{C}$ ) at medium cooling rates (Goldshtain, Grachev, \& Veksler, 1985). Therewith, mechanisms of ferrite precipitation strengthening are known to take action contributing higher tensile strength properties to the steel (Goldshtain, Grachev, \& Veksler, 1985). The referenced low- carbon steel was micro-alloyed by B in order to raising its plasticity. The plasticizing effect of B in low - carbon and low-alloyed steels was clearly described in the studies (Parusov et al., 2004; Parusov, Sychkov, \& Parusov, 2012; Parusov, Sychkov, Derevyanchenko, \& Zhigarev, 2005; Sychkov et al., 2009).

The billets employed in the experiments were $410 \times 500 \mathrm{~mm}$ in cross section, created via continuous casting and subsequently re-rolled into 150 sq. mm billets for further rolling on a 400/200 section rolling mill.

The re-rolled 150 sq. $\mathrm{mm}$ billets from the steel under study were heated in a continuous furnace of the rolling mill at $1160-1165{ }^{\circ} \mathrm{C}$ (Zone 5), $1145-1150{ }^{\circ} \mathrm{C}$ (Zone 6), $1110-1130{ }^{\circ} \mathrm{C}$ (Zone 7). The average temperature of the semi-rolled product after Stand 20 (Figure 2) was $1090^{\circ} \mathrm{C}$. 
To implement TMCR method (Figure 1, right-hand side) in order to manufacture 6. 0 - mm-diameter reinforcing wire in coils by V-alloyed $\mathrm{C}-\mathrm{Mn}-\mathrm{Si}$ - steel with $\mathrm{DP}$ - and MP microstructures and a required combination of tensile strength and plasticity properties, rib geometry, a series of industrial experiments were conducted at different laying head temperatures $\left(\mathrm{T}_{\mathrm{LH}}\right)$ (Figure 2).

Optical microscopy and scanning electron microscopy (SEM) methods were used by studying structures of reinforcement wires.

\section{Results and Discussions}

The micro-structural analysis has shown that MP - (ferrite-pearlite-martensite(bainite)) structures formed in 6.0 $\mathrm{mm}$-diameter profiled reinforcing wire from $\mathrm{V}$-alloyed $\mathrm{C}-\mathrm{Mn}-\mathrm{Si}$ - steel at higher temperatures $\mathrm{T}_{\mathrm{LH}}$ under the conditions of rolling schedules 3 and 5, while DP - (ferrite - martensite (bainite)) structures - at lower temperature $\mathrm{T}_{\mathrm{LH}}$ under the conditions of rolling schedule 10 (Figure 3, Table 7).

Also, wires treated under the conditions of TMCR schedules 3, 5 and 10 exhibited a high quality of the rib geometry, as it appeared in Figure 4.

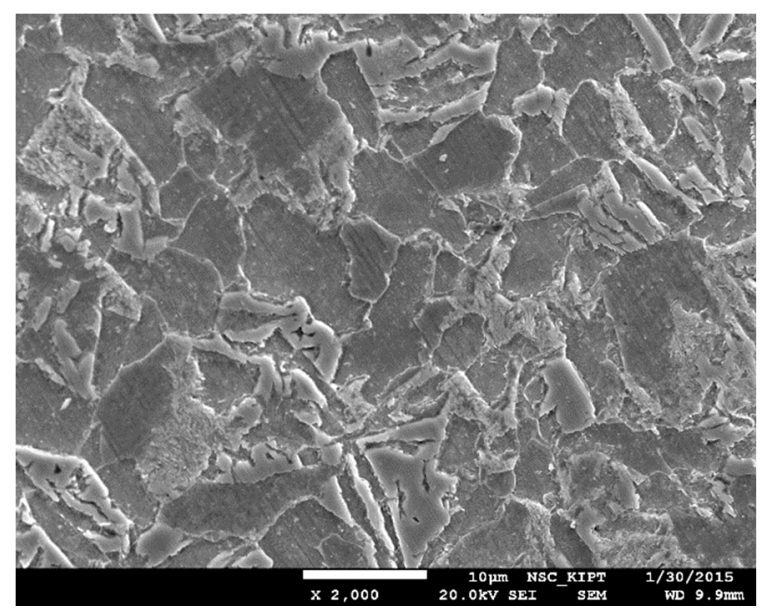

a)

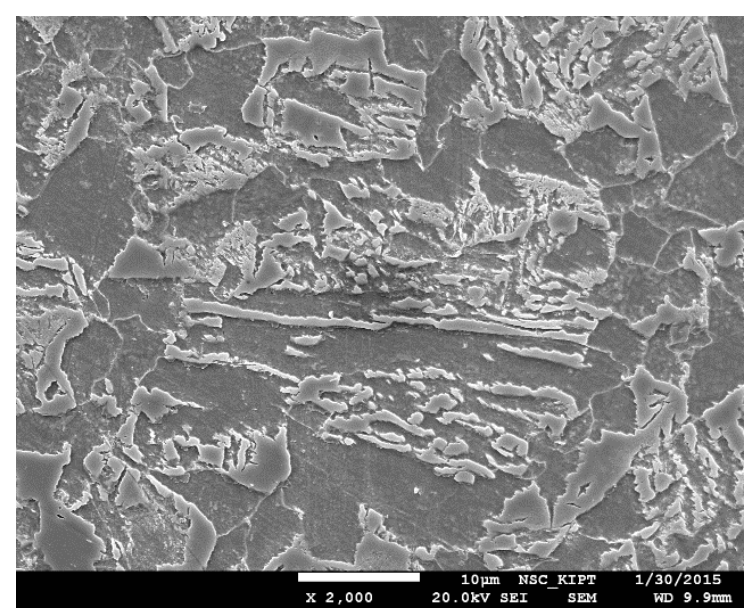

b)

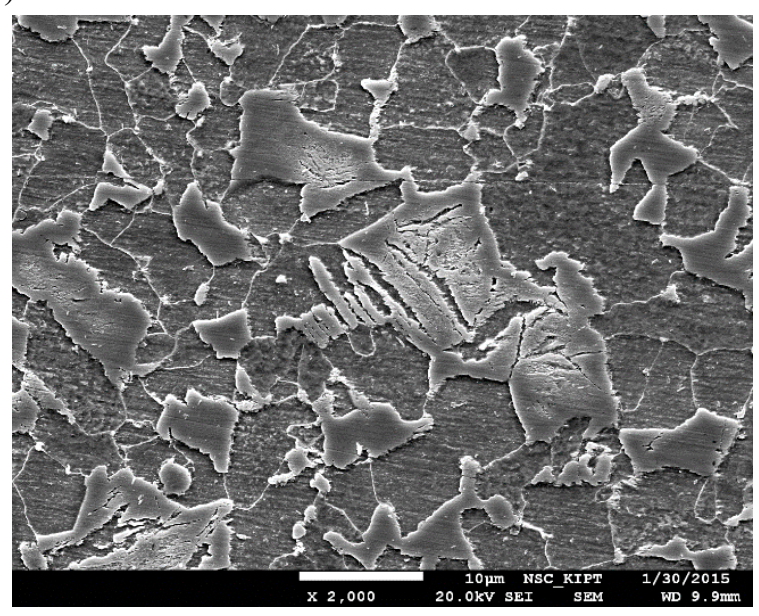

c)

Figure 3. SEM micrographs of 6.0-mm-diameter profiled reinforcing wire from V-alloyed C - Mn - Si - steel: a, b, $\mathrm{c}-$ the microstructures obtained under the conditions of TMCR schedules 3,5 and 10 respectively. 
Table 7. Most favorable TMCR schedules* and obtained mechanical properties

\begin{tabular}{|c|c|c|c|c|c|c|c|}
\hline Steel grade & $\begin{array}{l}\text { Schedule №. } \\
\text { (Sample №.) }\end{array}$ & $\begin{array}{l}\text { Water flow rate at water box } \\
\text { No. } 3, \mathrm{~m}^{3} / \mathrm{h} \\
\end{array}$ & $\mathrm{T}_{\mathrm{LH}},{ }^{\circ} \mathrm{C}$ & $\begin{array}{l}\mathrm{YS}_{0.2} \\
\mathrm{MPa}\end{array}$ & $\begin{array}{l}\mathrm{TS}, \\
\mathrm{MPa} \\
\end{array}$ & $\mathrm{El}_{5}, \%$ & Bending \\
\hline \multirow{6}{*}{$\begin{array}{l}\text { Micro-alloyed by V } \\
\mathrm{C}-\mathrm{Mn}-\mathrm{Si}-\text { steel }\end{array}$} & \multirow{2}{*}{3} & \multirow{2}{*}{53} & \multirow{2}{*}{1024} & 540 & 885 & 15.0 & Pass \\
\hline & & & & 530 & 810 & 26.0 & Pass \\
\hline & \multirow{2}{*}{5} & \multirow{2}{*}{0 (air cooling) } & \multirow{2}{*}{1063} & 550 & 805 & 21.5 & Pass \\
\hline & & & & 550 & 785 & 29.0 & Pass \\
\hline & \multirow{2}{*}{10} & \multirow{2}{*}{98} & \multirow{2}{*}{921} & 495 & 800 & 7.0 & Pass \\
\hline & & & & 490 & 775 & 11.0 & Pass \\
\hline Referenced & \multirow{3}{*}{3.1} & \multirow{3}{*}{98} & \multirow{3}{*}{920} & \multirow{3}{*}{410} & \multirow{3}{*}{565} & \multirow{3}{*}{31.0} & \multirow{3}{*}{ Pass } \\
\hline micro-alloyed by B & & & & & & & \\
\hline low - carbon steel & & & & & & & \\
\hline
\end{tabular}

* Note: All rolling schedules were carried out under the same operating conditions: the blowers 1-5, 7-10 were switched on and all thermo-insulated covers of the Stelmor line were opened.
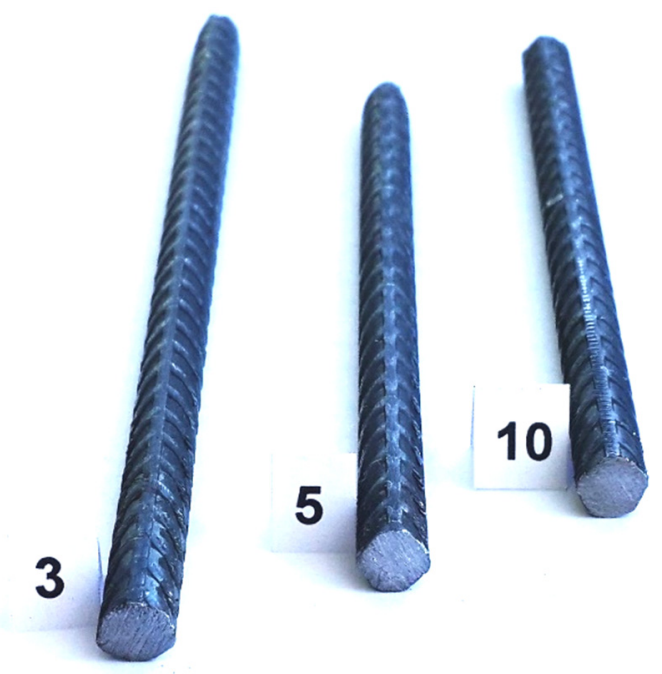

Figure 4. Samples of 6-mm-diameter V-alloyed C - Mn - Si - steel reinforcing wires manufactured under the conditions of TMCR schedules 3, 5 and 10 .

The specific heat of iron (steel) is $\rho=4.6 \times 10^{2} \mathrm{~J} / \mathrm{kg} \cdot \mathrm{K}$ (Novikov, \& Heinbuker, 2001). It means that the amount of heat to be removed to lower the temperature of $1 \mathrm{~kg}$ of steel by $1{ }^{\circ} \mathrm{C}$ is $4.6 \times 10^{2} \mathrm{~J}$. In the experiments, the heat was removed from the rings of reinforcing wires on the Stelmor conveyor by the streams of air from blowers below the rings with opened insulated covers (Figure 2, Table 7). These operating conditions remained unchanged for all TMCR schedules.

Since the operating conditions of the conveyor were the same for all experiments TMCR schedule 5 with TLH= $1063^{\circ} \mathrm{C}$ required more time to get wire's rings cooled down to austenite transformation temperatures compared with those TMCR schedules, which had lower TLH (Table 7). The analysis of austenite CCT-diagram in C - Mn $\mathrm{Si}$ - steel (Figure 5), which has a similar chemical composition with $\mathrm{C} \mathrm{Mn}-\mathrm{Si}$ - steel under study, indicated that the steel structure (Fig $3 \mathrm{~b}$, Table 8) obtained under the conditions of TMCR schedule 5 at $\mathrm{T}_{\mathrm{LH}}=1063^{\circ} \mathrm{C}$ had been formed via austenite phase transformations that were similar to those observed along cooling curve 5 .

The microstructure of reinforcing steel obtained under the conditions of TMCR schedule 3 at TLH $=1024{ }^{\circ} \mathrm{C}$ (Figure 3 a, Table 8 ) indicates that austenite transformations occurred along cooling curve 3 as shown in the CCT-diagram in Figure 5. The DP (ferrite-martensite (bainite)) - microstructure in the reinforcing steel under study which was formed under the conditions of TMCR schedule 10 (Figure $3 \mathrm{c}$, volume fraction of martensite (bainite) $-21.10 \%$, Table 8 ) is typical of the pearlite-free area range of cooling rates on the CCT-diagram (cooling curve 10, Figure 5). 
In 6.0 - mm-diameter reinforcing wires in coils from the referenced micro--alloyed by B low - carbon steel after treatment under the conditions of TMCR schedule 3.1, which parameters were similar to those of schedule 10 (Table 7), Widmanstätten structure formed with well-defined needle-type ferrite and isolated dark areas of fine pearlite (Figure 6). Generally, the volume fraction of free ferrite (FF with ferrite grain size $\mathrm{d}_{\mathrm{fg}}=0.00510 \mathrm{~mm}$ №.12 as per ASTM E112, Table 8) in the steel structure was comparable with the fraction of needle-type ferrite, which were $\mathrm{V}_{\mathrm{FF}}=41.43$ and $\mathrm{V}_{\mathrm{NT}}=46.17 \%$ respectively. The volume fraction of isolated pearlite areas was small $\left(\mathrm{V}_{\mathrm{IPA}}=12.40 \%\right)$, which together with a considerable share of soft ferrite fractions $\left(\mathrm{V}_{\mathrm{FF}}+\mathrm{V}_{\mathrm{NT}}=87.6 \%\right)$ determined a generally low level of tensile strength properties in 6.0 - mm-diameter reinforcing wire from the referenced steel (Table 7).

The analysis of ferrite structures in the reinforcing steel under study indicated, that fine $\mathrm{d}_{\mathrm{fg}}$ № 12 as per ASTM E112 (Table 8) was formed in this steel under the controlled cooling conditions by $\mathrm{T}_{\mathrm{LH}}=920^{\circ} \mathrm{C}-1063{ }^{\circ} \mathrm{C}$. It is beneficial for obtaining high tensile strength values in $\mathrm{V}$-micro-alloyed $\mathrm{C}-\mathrm{Mn}-\mathrm{Si}$ - steel reinforcing wire in diameter $6.0 \mathrm{~mm}$. For this wire the most favorable ratio of strengthening fractions (martensite (bainite) and pearlite - Figure $3 \mathrm{~b}$, Table 8 ) in its structure and the combination of tensile strength and plasticity properties (Table 7) can be obtained under the conditions of TMCR schedule 5 at $\mathrm{T}_{\mathrm{LH}}=1063{ }^{\circ} \mathrm{C}$.

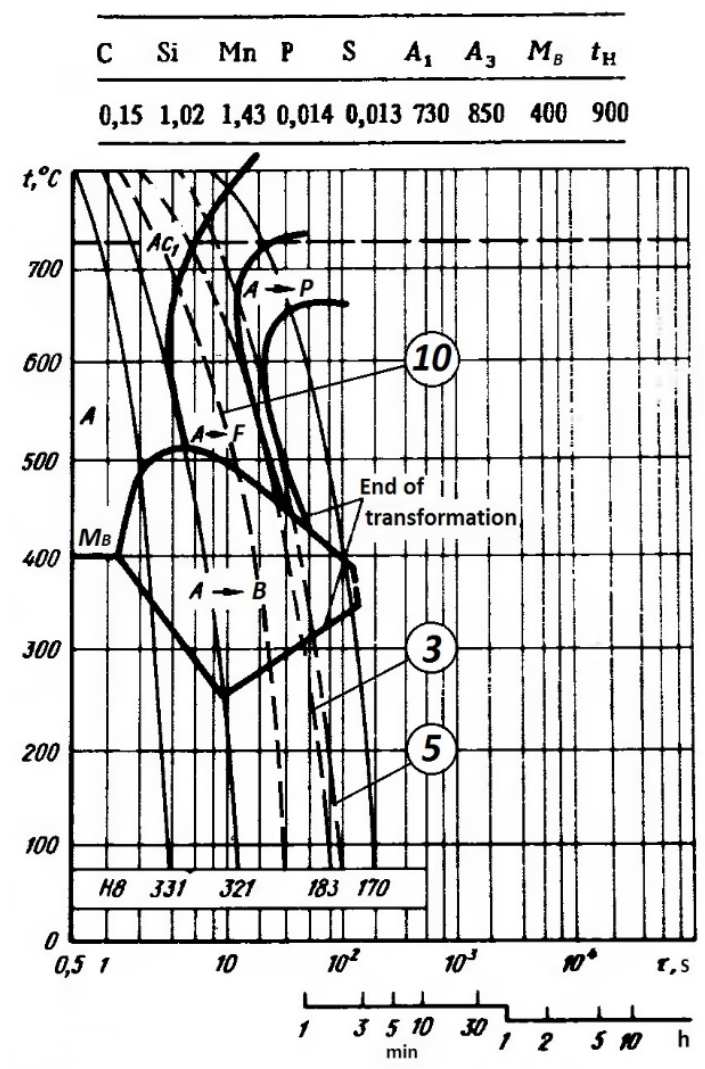

Figure 5. CCT-diagram of austenite transformations in C - Mn -Si - steel (Popov \& Popova, 1961; Popova \& Popov, 1991). Cooling curves of TMCR schedules 3, 5 and 10 (Table 7) are shown as dashed lines.

Table 8. Volume fraction of structures and ferrite grain sizes in V-micro-alloyed $\mathrm{C}-\mathrm{Mn}$ - Si - steel reinforcing wire in diameter $6.0 \mathrm{~mm}$

\begin{tabular}{ccccc}
\hline \multirow{2}{*}{$\begin{array}{l}\text { TMCR schedules } \\
\left(\mathrm{T}_{\mathrm{LH}},{ }^{\circ} \mathrm{C}\right)\end{array}$} & \multicolumn{2}{c}{ Volume fraction, \% } & \multicolumn{2}{c}{ Ferrite grain size, $\mathrm{d}_{\mathrm{fg}}$} \\
\cline { 2 - 5 } & $\begin{array}{c}\text { Martensite } \\
\text { (bainite) }\end{array}$ & Pearlite & $\mathrm{mm}$ & $\begin{array}{c}\text { Number as per } \\
\text { ASTM E112 }\end{array}$ \\
\hline $3(1024)$ & 20.95 & 4.66 & 0.00465 & 12 \\
$5(1063)$ & 15.02 & 10.44 & 0.00423 & 12 \\
$10(921)$ & 21.10 & - & 0.00443 & 12 \\
\hline
\end{tabular}




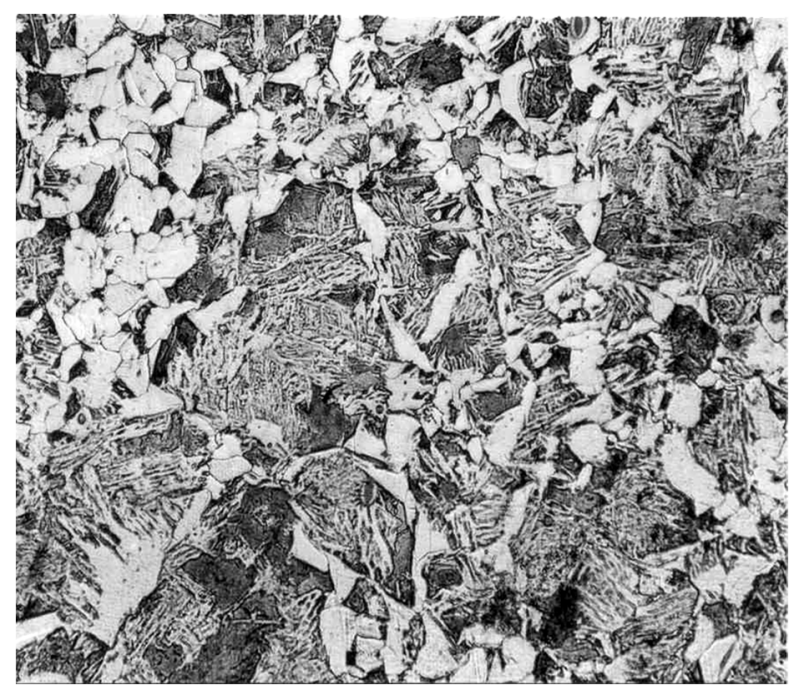

Figure 6. Microstructure of the core area in 6.0 - mm-diameter reinforcing wire of referenced micro-alloyed by B low - carbon steel; TMCR schedule 3.1 with $\mathrm{T}_{\mathrm{LH}}=920^{\circ} \mathrm{C}$; magnification $800 \mathrm{X}$

Under the conditions of this schedule and even schedule 3, despite a higher fraction volume of martensite (20.95\% - Table 8, Figure 3 a), the tensile strength and the plasticity of 6.0 - mm-diameter reinforcing wire in coils by $\mathrm{V}$-alloyed $\mathrm{C}-\mathrm{Mn}-\mathrm{Si}$ - steel are superior to the values specified in national standard specifications adopted in the USA, Japan and the Republic of Korea for high tensile strength rolled products (Table 2). Apparently, the high tensile strength of reinforcing wire from this steel is ensured by the additive contribution of grain boundary strengthening, phase strengthening due to the formation of martensite-bainite and pearlite areas, and strengthening of ferrite by vanadium carbon-nitride precipitations.

Tensile strength and plasticity properties of 6.0 - $\mathrm{mm}$ - diameter reinforcing wire in coils of the referenced micro alloyed by B low - carbon steel (Table 7) meet the requirements of national standard specifications adopted in the USA, Japan and the Republic of Korea for low strength rolled products: Gr. 40 and SD40 respectively (Table 2).

\section{Conclusions}

1. Thermo-mechanical controlled rolling (TMCR) schedules have been determined for the wire line of 400/200 section rolling mill, that ensure manufacture of $6.0-\mathrm{mm}$-diameter hot - rolled reinforcing wire in coils from V-alloyed C - Mn - Si - steel with dual-phase (DP - ferrite-martensite (bainite)) and multi-phase (MP ferrite-martensite (bainite) - pearlite) microstructures.

2. It has been established that high strength and plasticity characteristics $\left(\mathrm{YS}_{0.2}=530-550 \mathrm{MPa} ; \mathrm{TS}=785-885\right.$ $\mathrm{MPa} ; \mathrm{El}_{5}=15.0-29.0 \%$ ) were achieved in reinforcing wire of $6.0-\mathrm{mm}$ diameter in coils from the steel under study, which were in full compliance with the requirements of national standard specifications adopted in the USA, Japan and the Republic of Korea (ASTM A 615, JIS G 3112 and KSD 3504 respectively) for high tensile strength reinforcing wire, when the TMCR schedules involving laying head temperatures $\mathrm{T}_{\mathrm{LH}}$ from $1024{ }^{\circ} \mathrm{C}$ to $1063{ }^{\circ} \mathrm{C}$ were applied ensuring formation of a MP - microstructure.

\section{References}

Goldshtain, M. I., Grachev, S. V., \& Veksler, G. M. (1985). Special steels. M., Metallurgy, 1985, 408 P. (in Russian).

Lis, J., Lis, A., \& Kolan, C. (2004). Dual-phase technology and properties of C-Mn steels. Inżynieria Materiałowa, 25(3), 163-165.

Lorusso, H., Burgueno, A., Egidi, D., \& Svoboda, H. (2012). Application of dual phase steels in wires for reinforcement of concrete structures. Procedia Materials Science, 1, 118-125.

Novikov, I., \& Heinbuker, B. (2001). Physics: Toronto/Vancouver. Canada, Irvin Publishing.

Parusov, V. V., Sychkov, A. B., \& Parusov, E. V. (2012). Theoretical and technological basics for the production of high performance steel wire rod. ART-PRESS, Dnepropetrovsk, 376 P. 
Parusov, V. V., Sychkov, A. B., Derevyanchenko , I. V., \& Zhigarev, M. A. (2005). New application of boron in metallurgy. Bulletin of Nosov Magnitogorsk State Technical University, 1(9), 15-17. (in Russian).

Parusov, V. V., Sychkov, A. B., Zhigarev, M. A., \& Perchatkin, A. V. (2004). Wire rod of boron-bearing low-carbon steel for direct deep drawing. metallurgist, 48(11), 626-634.

Popov, A. A., \& Popova, L. E. (1961). Heat treater's guide. Isothermal and CCT-diagrams of the decomposition of overcooled austenite. Sverdlovsk, Mashgiz. (in Russian).

Popova, L. V., \& Popov, A. A. (1991). Phase transformation diagrams of Austenite and Beta-solution of titanium alloys. M: Metallurgy. (in Russian).

Sychkov, A. B., Sheksheev, M. A., Malashkin, S. O., \& Kamalova, G. Y. (2016). In-line heat treatment of long products and sections. Treatment of solid and sandwiched materials, 2016, №.2, pp. 5-24. (in Russian).

Sychkov, A. B., Parusov, V. V., Nesterenko, A. M., Zhukova, Y. S., Zhigarev, M. A., Perchatkin, A. V., ... Chuyko, I. N. (2009). Structure and properties of wire rod for electrodes and welding wire. Bendery, Poligraphist, 2009, 608 P. (in Russian).

Sychkov, A. B., Zhigarev, M. A., \& Perchatkin, A. V. (2006). Manufacture of reinforcing steel rolled products for wide applications. Technological peculiarities, Magnitogorsk, Publishing House of Nosov Magnitogorsk State Technical University, 2006, p. 499. (in Russian).

Wire Enforcement Institute (WRI). (2014). Historical Data on Wire, Triangular Wire Fabric/ Mesh and Welded Wire Concrete Reinforcement (WWR).

Xu, X. J., \& Kong, J. Q. (2012). Study on Cooling Process of Hot Rolled Wire Rod with Dual Phase Microstructure. In Advanced Materials Research (Vol. 415, pp. 779-783). Trans Tech Publications.

Zuo, X., \& Zhou, Z. (2015). Study of pipeline steels with acicular ferrite microstructure and ferrite-bainite dual-phase microstructure. Materials Research, 18(1), 36-41.

\section{Copyrights}

Copyright for this article is retained by the author(s), with first publication rights granted to the journal.

This is an open-access article distributed under the terms and conditions of the Creative Commons Attribution license (http://creativecommons.org/licenses/by/4.0/). 